\title{
Peculiarities of organization of propaganda of non-Olympic sports in Kharkiv
}

\author{
Svetlana Stadnik ${ }^{1}$ \\ Taras Bondar ${ }^{2}$ \\ Olena Orlenko ${ }^{1}$ \\ Irina Petrenko'
}

\author{
${ }^{1}$ Kharkiv State Academy of Physical Culture, Kharkiv, Ukraine \\ ${ }^{2}$ University of Customs and Finance, Dnipro, Ukraine
}

\begin{abstract}
This work is actual due to rapid growth of the popularity of non-Olympic sports in the city of Kharkiv. Identification of organizational reserves in non-Olympic propaganda system of sports in the city of Kharkiv and identification of areas of its improvement is aimed at the development of non-Olympic movement in the city.

Purpose: definition of features and ways to improve the system of propaganda of non-Olympic sports in the city of Kharkiv. Material \& Methods: during the research a set of scientific methods was used: Analysis of literary sources; Analysis of documentary materials; Analysis of Internet resources; System analysis; Organizational analysis; Survey (questionnaire), methods of mathematical statistics. In a study coaches and clients of fitness clubs in Kharkiv and students of Kharkiv sate academy of physical culture who are involved in non-Olympic sports $(n=50)$ participated.

Results: a system of propaganda of non-Olympic sports in the city of Kharkiv from the perspective of a systematic approach is characterized. Analyzed local promoter activity of management of the State's authority s in the sphere of physical culture and sport, the Federation and the other sports organizations of non-Olympic sports. The regional mass media have been identified, which cover information on non-Olympic sports. Organizational reserves are revealed.

Conclusions: the propaganda system of non-Olympic sports in the city of Kharkiv is characterized by its singularities in use of existing forms and means of propaganda in the existing resource provision and in regional media. Directions of improving the system of propaganda of non-Olympic sports in the city of Kharkiv are offered.
\end{abstract}

Keywords: system, reserves, directions, improving, activities.

\section{Introduction}

The modern practice of functioning and development of non-Olympic sports, as well as its social importance, are subjects of scientific interest. The need to research various aspects of system of non-Olympic sports is pointed by researches of scientists [5]. So far, in the literature the authors have presented the historical aspects of the emergence and development of non-Olympic sports, organizational and legal bases of non-Olympic sports regulation in the world and in Ukraine [8]. N. G. Dolbysheva \& E. Yu. Savaretz analyzed the main directions of activity of controls authorities that provide non-Olympic sports in Ukraine [4]. Actual problems and prospects of development of strategy of non-Olympic sports in Ukraine are presented in works [9; 11].

In official documents which regulate the sphere of physical culture and sport, it is emphasizes that the first important task is forming in the population needs to systematic physical culture and sports. This underlines the great importance of propaganda in the development of non-Olympic movement. In domestic literature $[3 ; 12]$ and foreign authors [13; 14] the role of propaganda and influence of the media on the development of sport, in particular the impact of social networks on sports sponsorship and marketing are examined [17; 20; 21].

In works of some authors $[1 ; 3 ; 6 ; 10 ; 12]$ the beginning of solution of studied problem has been started. In particular: study by A. A. Tomenko related to the study of non-Olympic sports' coverage of issues in the domestic media [12]. S. A. Stadnik \& M. A. Skrinnik characterized regional media as propaganda sources of non-Olympic sports [10]. Yu. N. Zhdamirova \& I. V. Petrenko considered mass physical culture and sports activities that take place in the city of Kharkiv [6].
A. Yu. Aghyppo \& A. S. Bondar presented sports and recreational sports organizations in Kharkiv [1]. A. S. Bondar \& V. S. Mamay especially paid attention to the lighting of Olympic and non-Olympic sports on the Internet [3]. At the same time, there are unresolved questions of the functioning and science provement of organization of propaganda for the development of non-Olympic sports in the city of Kharkiv.

Studying the system of propaganda of non-Olympic sports in the city of Kharkiv with the system approach aimed at identification of its characteristics and organizational reserves. This will provide an opportunity to identify areas for improvement of the existing non-Olympic sports promotion system that will contribute to the development of non-Olympic movement in the city of Kharkiv.

Purpose of the study: to define the features and directions of improvement the system of propaganda of nonOlympic sports in the city of Kharkiv.

\section{Material and Methods of the research}

Participants. Coaches and clients of fitness clubs in Kharkiv ( $n=29)$, as well as $3 d$-grade students of the Kharkiv state academy of physical culture, involved in non-Olympic sports $(n=21)$, took part in the study. 50 people were interviewed, $58 \%$ of them men and $42 \%$ women. The average age of respondents was $21-30$ years $-58 \%$, the maximum $41-50$ years $-16 \%$, the minimum - up to 20 years (4\%). All respondents are involved in non-Olympic sports and have lived in the city of Kharkiv for at least 5 years. All participants gave informed consent to participate in this survey.

Organization of research. In order to identify the state of development of non-Olympic sports in the city of Kharkiv, as well as to determine the content of propaganda of activ- 


\section{SLOBOZANS'KIJ NAUKOVO-SPORTIVNIJ VISNIK}

ity, methods of analysis of legal documents and analysis of Internet resources were used. The method of system analysis made it possible to determine the structural characteristic of the system of propaganda of non-Olympic sports in the city of Kharkiv. Application of the method of organizational analysis made it possible to identify organizational reserves. The survey was conducted in the form of a questionnaire in order to identify the opinion of Kharkiv inhabitants as for organization of propaganda of non-Olympic movement in the city of Kharkiv.

Statistical analysis. Excel program was used in the study.

\section{Results of the research}

In our study "a system of propaganda of non-Olympic sports", was seen as a set of interrelated or interacting elements which common goal is to convince the population of the city of Kharkiv in the use and need of training non-Olympic sports. It is found that the propaganda of non-Olympic sports system consists of the external environment, input, output and feedback of the final result of the system.

The external environment is a combination of factors that influence propaganda activities. Joining to non-Olympic sports propaganda is propaganda subjects, which we conventionally combined into 3 groups. This element, influenced by the external environment, using forms and means of propaganda, existing resources, regional media, influence the object of propaganda with the aim of achieving the final result at the output. Usage of a systematic approach requires a feedback to determine the importance of the processes in the operation of the system.

Local authorities in the city of Kharkiv, presented by the Department of Family, Youth and Sports of the Kharkiv City Council (hereinafter - the Department) and its structural divisions: Management and marketing department in the field of sport; Management department of physical culture and sports; Management Investment Development and image projects, as well as the Committee on the Family, Youth and Sports in the 9 districts of the city.

Objectives and activities of the Department and its business units, aimed at promoting sports movement, including non-Olympic sports are identified. These are tasks of organizing and carrying out and, taking into account the complex market research, large-scale sporting events, as well as their promotion on the Internet, in regional, national and international media.

It was found that the Department held in the city every year image sports events on the development of non-Olympic view s sports festival of extreme sports; social project "I can"; Martial arts festival; Sports fair "Kharkiv - the sports capital"; Festival on intellectual sports "Intelliada"; Sports corporate tournament "The Battle of Corporations"; Competition "Sports initiatives of Kharkiv". The results of the survey give grounds to assert that the above mentioned image-sports events rise interest in the city's population. In particular, $66 \%$ of respondents would like to become a part of such events.

The analysis of calendar plans of the Administration of Physical Culture and Sports Department has shown that each year the city hosts about 300 sports events. Out of them, $60 \%$ are activities of non-Olympic sports. In the course of our survey it is revealed that the majority $(66 \%)$ of respondents are interested in sports events that are held in the city on the power non-Olympic sports (weightlifting, arm sport, bodybuilding, power lifting, strongman).
At the same time, the analysis of propaganda activities of local government authorities in the field of Physical Education and Sports has revealed the organizing reserve. This project of the city target complex program to promote non-Olympic sports in the regional media, coordination and control over the implementation of which is entrusted to the Department of Family, Youth and Sports of the Kharkiv City Council and its structural divisions.

To public sports organizations which develop non-Olympic sports in the city of Kharkiv, we attribute the federation of non-Olympic sports and sports society. It was revealed that currently in Kharkiv there are 65 regional and city federations of non-Olympic sports. As our research has shown, the federation promotes sport through sports events, championships, cups; participation in national and international competitions in sports and public events that take place in the city, in the country; establishing contacts with different levels of government, educational institutions, businesses, institutions; Organization and holding of meetings with successful sportsmen, coaches, sports functionaries of the federation on the basis of educational institutions of all levels, enterprises, institutions; Production and distribution of booklets, posters, banners, brochures, leaflets; placing news reports and interviews in the media, creating websites or pages on social networks and others.

In addition to sports federations in Kharkiv, popularization of non-Olympic sports makes Kharkiv regional organization of sports society "Dynamo" (the FSS "Dynamo"). The analysis of schedules of fitness and sports activities of FSO "Dynamo" during 2013-2016 years has shown that the city annually held championships "Dynamo" according to the program of complex competitions "Dinamiada", "Olympics" and "OlympicsHealth" in non-Olympic and professional kinds of sport.

The results of the survey show that in the city of Kharkiv, according to the respondents, mostly develop various nonOlympic kinds of martial arts (84\%), as well as such nonOlympic sports such as bodybuilding (66\%), power lifting $(58 \%)$, fitness $(50 \%)$. This is ensured by the operation of private sports schools of martial arts, fitness-clubs, fitness centers, etc.

It was revealed that today in the city operates 145 fitness clubs, 37 CYSS of state, communal property forms, as well as sports and subordinate companies and agencies. The number of pupils there is 62789 . CYSS of the city cultivate 14 nonOlympic sports.

In Kharkiv regional high school of physical training and sports, along with sport reserve, training of Olympic sports branch in chess is functioning.

Kharkiv is also known for the development of non-Olympic kinds of sports as rugby league. First of Rugby League team "Legion XIII" (rugby-13), was created precisely in Kharkiv in 2006 .

The study showed that in the city extreme sports are also developing on the basis of Kharkiv flying club named after V. S. Grizodubova, climbing club "Format", and mountaineering club, rollerblading "Ya-roller", Kharkiv regional hang gliding club, "Pioneer" Karting Club, "Leader", "Metallist", "Duffy", skate park. However, as the results of our survey showed, only $16 \%$ of respondents noted that they happily spend their free time skipping with a parachute, or doing sports tourism, paintball, carting.

Active rest of residents and visitors of the city is provided by functioning $\mathrm{s}$ squash courts, a bowling club $\mathrm{s}, \mathrm{x}$ Billiard clubs, paintball Cloud $b$ on in. For example, a petanque 


\section{СЛОБОЖАНСЬКИЙ НАУКОВО-СПОРТИВНИЙ ВІСНИК}

club "Fair Play", Ukraine's only golf resort "Superior", sportshooting club "AFAR-Ukraine". These are non-state actors that have a population of paid sports and health services, and realize boiling its activities through its own commercial and business activities.

An important element of our propaganda system is the regional mass media (mass media). In our study, there are defined 6 radio stations, 10 newspapers and magazines, 15 television channels as well as Internet resources, which provide information of non-Olympic sports. Identified organizational reserve, this is the creation of specialized regional media for non-Olympic sports (television or internet channels, telecast, website, magazine or newspaper), substantial part of which will be not only informative and advertising, but also cognitive, analytical. Another organizational reserve is the organization of trainings for workers of federations and other organizations of non-Olympic sports to create effective advertising and administer their own Internet sites.

During the study, the respondents' assessment of the organization of the propaganda of non-Olympic sports in Kharkiv was revealed. In particular, $50 \%$ of respondents rated the level of the organization as low and the remaining $50 \%$ as average. In our opinion, such assessment demonstrates the need to activate the organizational reserves, identified by us in the activities of state and public authorities, sports and sports organizations, regional media on the promotion of nonOlympic sports in the city of Kharkiv.

\section{Conclusions / Discussion}

The modern practice of functioning and development of non-Olympic sports necessitate conducting of integrated research in order to identify trends in the formation of new concepts and developing innovative technologies to ensure the organizational and management system of non-Olympic sport. We share the opinion of M. Dutchak \& N. Dolbysheva [5] that among the prospective areas of research of problems of features of development of non-Olympic sports important place is occupied by analysis of local executive bodies and public organizations of physical culture and sports orientation.

In our study, propaganda of non-Olympic sports in the city of Kharkiv was first considered from the perspective of systematic approach. The system approach in the field of physical culture and sports, according to N. V. Zhmarev [7] represents a methodological scientific approach aimed at identifying the elements of the system and analyze the interrelationships between them. Using the systematic approach to the study of the organization of promotional activities for the development of non-Olympic sports, we believe it is appropriate, as the system is social, artificial and open.

Previously, foreign authors considered the planning and management of sports events [15; 18; 19] It has been suggested [4] that, among the main directions of activity of state and public governing bodies ensuring the development of non-Olympic sport, are the preparation and conduction of competitions of various levels. Our research supplements existing data of the functioning and characteristics of the activities of state and public authorities in the field of physical culture and sports in the aspect of organizing propaganda of the development of non-Olympic sports in the city of Kharkiv.

The obtained results of the research confirm city's normative and programmatic documents, in particular, that the government bodies of the city of Kharkiv develop the sphere of physical culture and sports as a priority, having a strategic direction. Our data supplement the results of the study, which are outlined in the work of Yu. N. Zhdamirova \& I. V. Petrenko [6], concerning the activities of the Department of Family, Youth and Sports of the Kharkiv City Council as for the organization and holding of sports and mass image events.

Our research suggests that non-Olympic sports are fashionable and necessary for health promotion. This is the opinion of all $100 \%$ of respondents from Kharkiv and a number of researchers of the problems of development of non-Olympic sport in Ukraine [2; 8]. However, the results of the poll contradict the author's statement [1] that in the city of Kharkiv extreme popularity, especially among youth, is acquired by extreme non-Olympic sports. In particular, the majority of respondents $(84 \%)$ did not organize their active recreation in the city using extreme sports.

An important role in the promotion of non-Olympic sports is played by the media. Previously A. A. Tomenko pointed out that in Ukraine there are no specialized printed publications on non-Olympic sports. Our data supplement already existing data $[12 ; 16]$. In particular, we analyzed Kharkiv regional mass media (radio stations, print media, television channels, Internet resources) regarding the presentation of information about non-Olympic kinds of sport.

The results of our survey, as well as works [3; 10], show that Internet resources, including social networks, are the most popular among regional media $[17 ; 20]$. It was found out that the sports portal "Sports Kharkiv" has a special value in covering the non-Olympic sports in the city in terms of the number of views per day. For a day, this site has 2,732 views, for the month 81,960, and for a year almost a million 997,180 views.

In the regional normative and programmatic documents aimed at the development of the sphere of physical culture and sports, it is emphasized that all necessary conditions are created in the city to strengthen the health of the population. This position is only half confirmed by our studies in terms of the created conditions in the city for practicing non-Olympic sports. So $58 \%$ of respondents think, and the remaining $42 \%$ - adhere to the opposite point of view. According to $50 \%$ of respondents, it is necessary to strengthen the promotion of non-Olympic sports in the city. In our opinion, these respondents' answers give grounds to talk about improving the organization of the propaganda of non-Olympic sports in the city.

This study confirms the practical recommendations and suggestions of scientists engaged in studying the problems of development of non-Olympic sport [5; 8; 9; 11]. Our study also complements the above directions. For the first time, organizational reserves were identified in the existing system of propaganda of non-Olympic sports in the city of Kharkiv.

Thus, the organization of the promotion of non-Olympic sports in the city of Kharkiv has its own characteristics. Kharkiv is known for annual sports events of non-Olympic sports: festivals and extreme sports, martial arts, intellectual sports of the "Intelliada", etc. It is confirmed that the propaganda and development of the non-Olympic movement in the city is ensured by the functioning of local state government bodies, 65 regional and city federations of non-Olympic sports, FSO "Dynamo", 37 sports schools, 1 physical education college, 145 fitness clubs, teams of Rugby League "Legion XIII", flying club named after V. S. Grizdubova, 4 carting clubs, the only golf resort in Ukraine "Superior", etc. The results of our study indicate the need to improve the system of promoting nonOlympic sports in the city.

Based on the identified organizational reserves, we con- 


\section{SLOBOZANS'KIJ NAUKOVO-SPORTIVNIJ VISNIK}

sider it expedient to propose directions for improving the system of promoting non-Olympic sports in the city of Kharkiv. Firstly, comprehensive coverage of various aspects of nonOlympic movement in regional media by creating specialized printed publications, television and radio programs, portals, Internet sites, etc. Secondly, the optimization of the management of non-Olympic sports by local government authorities through the development of the city's targeted integrated program for the promotion of non-Olympic sports in regional media. Thirdly, the development of the activities of federations and other organizations in non-Olympic sports was for attracting sponsors, popularizing non-Olympic sports by organizing and conducting trainings on creating effective advertising and administering their own Internet sites.

Conflict of interests. The authors declare that no conflict of interest. Financing sources. This article didn't get the financial support from the state, public or commercial organization.

\section{References}

1. Azhyppo, O. \& Bondar, A. (2014), "Features of recreational and physical culture sports activities of children and youth in Ukraine", Sportyvna medytsina, No. 1, pp. 41-45. (in Ukr.)

2. Bondar, A.S. \& Warywoda, O.O. (2016), "The role of non-Olympic sport in modern society", Stratehichne upravlinnia rozvytkom fizychnoi kultury i sportu v konteksti 25-richchia nezalezhnosti Ukrainy: zbirnyk materialiv IV rehionalnoi naukovo-praktychnoi internet-konferentsii z mizhnarodnoiu uchastiu, Kharkiv, pp. 188-193. (in Ukr.)

3. Bondar, A.S. \& Mamaj, V.S. (2016), "Features of illumination of physical culture and sports in Internet resources", Zbirnyk naukovykh prats Kharkivskoi derzhavnoi akademii fizychnoi kultury, No. 3, pp. 75-78. (in Ukr.)

4. Dolbysheva, N.G. \& Savarets, E.Yu. (2012), "The main activities of the governing bodies providing non-Olympic sports in Ukraine", Slobozans 'kij naukovo-sportivnij visnik, No. 5, pp. 126-129. (in Russ.)

5. Dutchak, M.V. \& Dolbysheva, N.G. (2012), "Perspective directions of scientific research of peculiarities of functioning and development of non-Olympic sport in Ukraine", Sportyvnyi visnyk Prydniprovia, No. 1, pp. 202-206. (in Ukr.)

6. Zhdamyrova, Y.M. \& Petrenko, I.V. (2016), "Development of mass physical culture and sports in the city of Kharkiv", Stratehichne upravlinnia rozvytkom fizychnoi kultury i sportu v konteksti 25-richchia nezalezhnosti Ukrainy: zbirnyk materialiv IV rehionalnoi naukovo-praktychnoi internet-konferentsii z mizhnarodnoiu uchastiu, Kharkiv, pp. 117-121. (in Ukr.)

7. Zhmarev, N.V. (1984), Systemnyi podkhod i tselevoe upravlenye v sporte [System approach and target management in sport], Kiev. (in Russ.)

8. Imas, E.V., Matveev, S.F. \& Borisova, O.V. (2015), Neolimpiiskyi sport [Non-Olympic sport], Kiev, 184 p. (in Ukr.)

9. Leonov, Ya.V. \& Putyatina, G.M. (2014), "Strategic Prospects for the Development of the Neolympic Sport in Ukraine", Slobozans 'kij naukovo-sportivnij visnik, No. 5(43), pp. 29-34. (in Ukr.)

10. Stadnyk, S.O. \& Skrynnyk, M.A. (2017), "Regional mass media as a source of propaganda for non-Olympic sports", Stratehichne upravlinnia rozvytkom fizychnoi kultury i sportu: zbirnyk naukovykh prats, Kharkiv, pp. 166-171, available at: http://hdafk. Kharkiv.ua/ua/naukova-robota/dsrtet4 (in Ukr.)

11. Tikhonova, N.V. \& Gradusov, V.A. (2014), "The state of development of sports, technical and applied sports in the sports and fitness organizations of Ukraine", Pedahohika, psykholohiia ta medyko-biolohichni problemy fizychnoho vykhovannia i sportu, No. 10 , pp. 52-56.

12. Томенко, O.A. (2015), "Features of the coverage of the problems of the development of non-Olympic sports in the domestic mass media", Stratehichne upravlinnia rozvytkom fizychnoi kultury i sportu: zbirnyk materialiv III rehionalnoi naukovo-praktychnoi konferentsii za uchastiu mizhnarodnykh spetsialistiv, Kharkiv, pp. 157-162. (in Ukr.)

13. Afroozeh, M.S., Hamidi, M. \& Elahi, A. (2012), "Identification of Vantage points of Universities' Sports Council Members Regarding Media Approach to Sports", Journal of Research Communication, No. 19(1), pp. 55-70.

14. Asadi, A. \& Rezaee Soufi M. (2014), "Analysis of current situation and desirable role of mass media in development of volleyball sport field amongst students of sports sciences", Communication Management in Sports Media, No. 2(5), pp. 59-63.

15. Daniel Bjдrsholm (2017), "Sport and Social Entrepreneurship: a Review of a Concept in Progress", Journal of Sport Management, Vol. 31(2), pp. 191-206

16. Emami, M. \& Mallaei, M. (2013), "Analysis of Sports News Content: Case Study of Channel 3", Communication Management in Sports Media, No. 1(3), pp. 15-24

17. Gashaw Abeza, Ann Peqoraro, Michael I. Naraine, Benoit Sequin \& Norm O’Reilly (2014), "Activating a global sport sponsorship with social media: an analysis of TOP sponsors, Twitter, and the 2014 Olympic Games", International Journal of Sport Management and Marketing, Vol. 15, No. 3/4. pp. 184-213

18. Ghaith Rabadi, Wael Khallouli, Mohammed Al-Salem \& Ahmed Ghoniem (2015), "Planning and management of major sporting events: a survey", Journal of Planning and Scheduling, Vol. 2, No. 2, pp. 154-178.

19. Maenning, W. \& Zimbalist, A. (2013), International Handbook on the Economics of Mega sporting Events, Edward Elgar.

20. Michelle O'Shea \& Abel Duarte Alonso (2013), "Fan moderation of professional sports organisations' social media content: strategic brilliance or pending disaster?", International Journal of Web Based Communities, Vol. 9, No. 4, pp. 554-570.

21. Walid A. Nakara, Fatim-Zohra Benmoussa \& Annabelle Jaouen (2012), "Entrepreneurship and social media marketing: evidence from French small business", International Journal of Entrepreneurship and Small Business, Vol. 16, No. 4, pp. $386-405$

Received: 23.04.2019

Published: 30.06 .2019

Анотація. Світлана Стадник, Тарас Бондар, Олена Орленко, Ірина Петренко. Особливості організації пропаганди неолімпійського спорту у Харкові. Ця робота актуальна завдяки швидкому зростанню популярності неолімпійських видів спорту в місті Харкові. Виявлення організаційних резервів у неолімпійській пропагандистській системі спорту в місті Харкові та виявлення напрямів ї̈ вдосконалення спрямовано на розвиток неолімпійського руху в місті. Мета: визначення особливостей i шляхів удосконалення системи пропаганди неолімпійських видів спорту в місті Харкові. Матеріал і методи: у ході дослідження використовувався комплекс наукових методів: аналіз літературних джерел; аналіз документальних матеріалів; аналіз інтернетресурсів; системний аналіз; організаційний аналіз; опитування (анкета), методи математичної статистики. у дослідженні брали участь тренери та клієнти фізкультурних клубів Харкова та студенти Харківської державної академії фізичної культури, які беруть участь у неолімпійських видах спорту $(n=50)$. Результати: характеризується система пропаганди неолімпійських видів спорту в місті Харкові з точки зору системного підходу. Проаналізовано місцеву промоутерську діяльність керівництва органів державної влади у сфері фізичної культури і спорту, Федерації та інших спортивних організацій неолімпійських видів спорту. Визначено регіональні

Stadnik, S., Bondar, T., Orlenko, O. \& Petrenko, I. (2019), "Pecularities of organization of propaganda of non-Olympic sports in Kharkiv", Слобожанський науково-спортивний вісник, № 3(71), C. 5-9, doi:10.15391/snsv.2019-3.001
Stadnik, S., Bondar, T., Orlenko, O. \& Petrenko, I. (2019), "Peculiarities of organization of propaganda of non-Olympic sports in Kharkiv", Slobozans kij naukovo-sportivnij visnik, No. 3(71), pp. 5-9, doi:10.15391/snsv.2019-3.001 


\section{СЛОБОЖАНСЬКИЙ НАУКОВО-СПОРТИВНИЙ ВІСНИК}

ЗМІ, які охоплюють інформацію про неолімпійські види спорту. Виявлено організаційні резерви. Висновки: пропагандистська система неолімпійських видів спорту в місті Харкові характеризується особливостями використання існуючих форм і засобів пропаганди в існуючому ресурсному забезпеченні і в регіональних ЗМІ. Запропоновано напрями вдосконалення системи пропаганди неолімпійських видів спорту в місті Харкові.

Ключові слова: система, резерви, напрями, вдосконалення, діяльність.

Аннотация. Светлана Стадник, Тарас Бондарь, Елена Орленко, Ирина Петренко. Особенности организации пропаганды неолимпийского спорта в Харькове. Эта работа актуальна благодаря быстрому роступопулярности неолимпийским видам спорта в городе Харькове. Выявление организационных резервов в неолимпийской пропагандистской системе спорта в городе Харькове и выявления направлений ее совершенствования направлено на развитие неолимпийского движения в городе. Цель: определение особенностей и путей совершенствования системы пропаганды неолимпийских видов спорта в городе Харькове. Материал и методы: в ходе исследования использовался комплекс научных методов: анализ литературных источников; анализ документальных материалов; анализ интернет-ресурсов; системный анализ; организационный анализ; опроса (анкета), методы математической статистики. В исследовании принимали участие тренеры и клиенты физкультурных клубов Харькова и студенты Харьковской государственной академии физической культуры, участвующие в неолимпийских видах спорта (п=50). Результаты: характеризуется система пропаганды неолимпийских видов спорта в городе Харькове с точки зрения системного подхода. Проанализированы местную промоутерскую деятельность руководства органов государственной власти в сфере физической культуры и спорта, Федерации и других спортивных организаций неолимпийских видов спорта. Определены региональные СМИ, которые охватывают информацию о неолимпийских видах спорта. Выявлено организационные резервы. Выводы: пропагандистская система неолимпийских видов спорта в городе Харькове характеризуется особенностями использования существующих форм и средств пропаганды в существующем ресурсном обеспечении ив региональных Сми. Предложены направления совершенствования системы пропаганды неолимпийских видов спорта в городе Харькове.

Ключевые слова: система, резервы, направления, совершенствование, деятельность.

\section{Відомості про авторів / Information about the Authors}

Стадник Світлана Олександрівна: к. фіз. вих., Харківська державна академія фізичної культури: вул. Клочківська 99, м. Харків,61058, Україна.

Стадник Светлана Александровна: к. физ. восп., Харьковская государственная академия физической культуры: ул. Клочковская 99, г. Харьков, 61058, Украина.

Svitlana Stadnyk: PhD (Physikal Education and Srort), Kharkiv State Academy of Physikal Cuiture: Klochkivska str. 99, Kharkiv, 61058, Ukraine.

ORCID.ORG/0000-0001-6694-1098

E-mail: svetlanastadnik87@gmail.com

Бондар Тарас Сергійович: к. фіз. вих., Університет митної справи та фінансів: 49000, м. Дніпро, вул. Володимира Вернадського 2/4, Україна.

Бондарь Тарас Сергеевич: к. физ. восп., Университет таможенного дела и финансов: 49000, г. Днепр, ул. Владимира Вернадского 2/4, Украина.

Taras Bondar: PhD (Physikal Education and Srort), University of Customs and Finance: 49000, Dnipro, St. Volodymyr Vernadsky 2/4, Ukraine.

ORCID.ORG/0000-0002-1389-6614

E-mail: tsbondar@gmail.com

Орленко Олена: к. іст. н., Харківська державна академія фізичної культури: вул. Клочківська 99, м. Харків,61058, Україна.

Орленко Елена: к. ист. н., Харьковская государственная академия физической культуры: ул. Клочковская 99, г. Харьков, 61058, украина.

Olena Orlenko: PhD(History), Kharkiv State Academy of Physikal Cuiture: Klochkivska str. 99, Kharkiv, 61058, Ukraine.

ORCID.ORG/0000-0003-4436-487X

E-mail: olena_orlenko@ukr.net

Петренко Ірина Вікторівна: к. фіз. вих.; Харківська державна академія фізичної культури: вул. Клочківська, 99, м. Харків, 61058, Україна.

Петренко Ирина Викторовна: к. физ. восп.; Харьковская государственная академия физической культуры: ул. Клочковская, 99, г. Харьков, Украина.

Iryna Petrenko: PhD (Physical Education and Sport); Kharkiv State Academy of Physical Culture: Klochkivska str., 99, Kharkiv, 61058, Ukraine.

ORCID.ORG/0000-0003-4252-1130

E-mail: ivpetrenko18@ukr.net 